\title{
Prevalence of celiac disease in collagenous and lymphocytic colitis
}

\author{
Helen Rachel Gillett MD, Hugh James Freeman MD
}

\begin{abstract}
HR Gillett, HJ Freeman. Prevalence of celiac disease in collagenous and lymphocytic colitis. Can J Gastroenterol 2000;14(11):919-921. Both collagenous and lymphocytic colitis have been described in patients with celiac disease, suggesting an association between the conditions. Over the past few years, the availability, sensitivity and specificity of serological markers for celiac disease have improved - the most recent advancement being the description of tissue transglutaminase as the major antigen for endomysium antibody. A quantitative ELISA was used to measure titres of immunoglobulin A ( $\operatorname{IgA}$ ) antibody to tissue transglutaminase (tTG) along with an immunofluorescent technique for $\operatorname{IgA}$ endomysium antibody (EmA) in 15 patients with lymphocytic colitis and eight with collagenous colitis to determine whether celiac disease latency could be detected. One patient with lymphocytic colitis demonstrated both elevated titres of tTG antibody and positive EmA, and small bowel biopsy confirmed celiac disease. One patient with collagenous colitis had a slightly elevated titre of tTG antibody with a negative EmA, and results of a small bowel biopsy were normal. Three other patients with lymphocytic colitis were already treated for previously diagnosed celiac disease. The prevalence of celiac disease occurring in lymphocytic colitis was found to be $27 \%$, but no cases of celiac disease in association with collagenous colitis were found.
\end{abstract}

Key Words: Celiac disease; Collagenous colitis; Endomysium antibody; Lymphocytic colitis; Tissue transglutaminase

\section{Prévalence de la maladie coeliaque dans les colites collagène et lymphocytaire}

RÉSUMÉ: La colite lymphocytaire et la colite collagène ont toutes deux été signalées chez des patients souffrant de la maladie coeliaque, ce qui donne à penser qu'il existe un lien entre les deux maladies. L'analyse des marqueurs sérologiques de la maladie coeliaque ainsi que leur sensibilité et leur spécificité se sont améliorées au cours des dernières années, le progrès le plus notable étant la description de la transglutaminase tissulaire comme le principal antigène de l'anticorps anti-endomysium. On a procédé à un titrage des anticorps anti-transglutaminase tissulaire (TGt) de type immunoglobuline $\mathrm{A}(\mathrm{IgA})$ par la méthode ELISA ainsi qu'à une épreuve d'immunufluorescence pour la détection des anticorps $(\mathrm{Ac})$ anti-endomysium chez quinze patients souffrant de colite lymphocytaire et huit patients souffrant de colite collagène pour savoir s'il était possible de déceler une maladie coeliaque latente. Un patient atteint de colite lymphocytaire présentait à la fois un titre élevé d'anticorps anti-TGt et une épreuve positive d'Ac anti-endomysium; une petite biopsie de l'intestin a confirmé la présence de la maladie coeliaque. Par contre, un autre patient atteint de colite collagène présentait un titre légèrement élevé d'anticorps anti-TGt et une épreuve négative d'Ac anti-endomysium; la biopsie de l'intestin s'est avérée normale. Trois autres patients souffrant de colite lymphocytaire avaient déjà été traités pour une maladie coeliaque diagnostiquée antérieurement. La prévalence de la maladie coeliaque s'est élevée à $27 \%$ chez les patients atteints de colite lymphocytaire, mais aucun cas de maladie coeliaque n’a été associé à la colite collagène.

\footnotetext{
O ollagenous colitis (CC) and lymphocytic colitis (LC) have similar clinical and histopathological features; chronic watery diarrhea occurs with prominent chronic inflammation in the lamina propria, damaged colorectal epithelium and increased intraepithelial lymphocytes $(1,2)$. Similar features are seen within the small intestine in patients with celiac disease, and there have been reports of
}

concurrent celiac disease and collagenous or lymphocytic colitis (3-6).

Immunoglobulin A (IgA) endomysium antibody (EmA) is a sensitive and specific serological marker for celiac disease (7-9). Tissue transglutaminase (tTG) has been identified as the major antigen for EmA (10), enabling the establishment of an ELISA to measure IgA tTG antibody. This ELISA has

Division of Gastroenterology, Department of Medicine, University of British Columbia, Vancouver, British Columbia

Correspondence and reprints: Dr Helen Gillett, Gastroenterology - Room F 137, University Hospital, 2211 Wesbrook Mall, Vancouver,

British Columbia V6T 123. Telephone 604-822-7216, fax 604-822-7236, e-mail p.h.gillett@cableinet.co.uk

Received for publication March 19, 1999. Accepted November 30, 1999 
TABLE 1

Small bowel biopsy reports of 22 patients with collagenous or lymphocytic colitis

\begin{tabular}{ll}
\hline Number of biopsies & Histological report \\
\hline 20 & Normal \\
1 & $\begin{array}{c}\text { Moderately severe villous atrophy and } \\
\text { crypt hyperplasia } \\
\text { Normal villous architecture but increased } \\
\text { numbers of intraepithelial } \\
1\end{array}$ \\
\hline
\end{tabular}

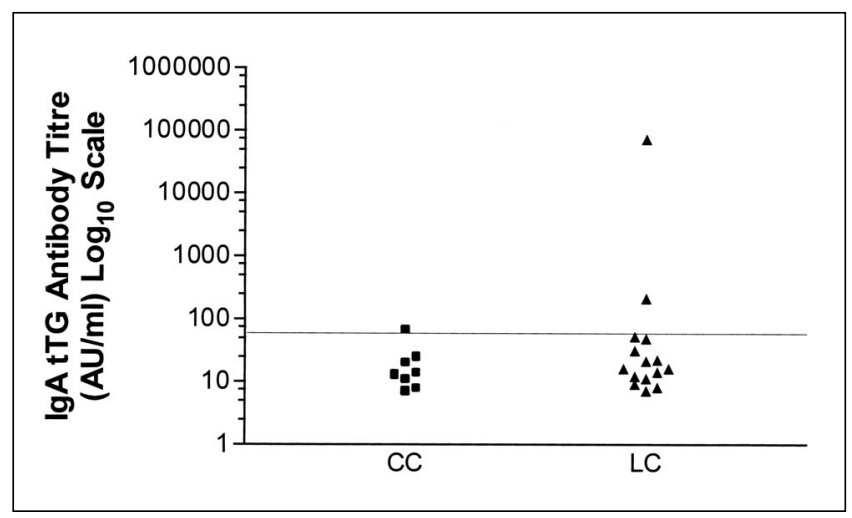

Figure 1) Titres of immunoglobulin A (IgA) tissue transglutaminase ( $t$ TG) antibody in patients with collagenous colitis (CC) and lymphocytic colitis (LC). The reference range is 4 to 60 arbitrary units $(\mathrm{AU}) / \mathrm{mL}$. The horizontal line indicates the upper limit of the reference range

been found to be both sensitive and specific for celiac disease $(11,12)$. We investigated whether patients with CC or LC exhibited IgA EmA or IgA tTG antibody in serum.

\section{PATIENTS AND METHODS}

Patients: Twenty-three patients - 20 female and three male - were studied. Fifteen had a diagnosis of lymphocytic colitis and eight collagenous colitis. The mean age was 56.7 years (range 25.7 to 83.3 years). Fifteen patients (11 with LC and four with CC) were not on medication for their colitis at the time of the study; three (two CC, one LC) were on oral corticosteroids, three (two CC, one LC) were on acetylsalicylic acid preparations, and two with LC were on antidiarrheal agents.

Three patients with LC had also received a diagnosis of celiac disease and were treated with a gluten-free diet.

Serum was collected from each patient and tested for IgA $\mathrm{EmA}$ and IgA tTG antibodies.

Serological testing: IgA EmA was tested by using indirect immunofluorescence against human umbilical cord as described by Ladinser et al (8). Samples were tested at 1:5 dilution.

IgA antibodies to tTG were detected using an ELISA, as described by Dieterich et al (11). Samples were tested initially at 1:5 dilution, with high samples diluted further until a titre was obtained. Titres were measured in arbitrary units $(\mathrm{AU}) / \mathrm{mL}$ by comparison with a standard serum.

Small bowel biopsy: Distal duodenal biopsies were taken endoscopically and examined by the hospital pathology department and by one of the authors.

\section{RESULTS}

Small bowel biopsy: Biopsy results of 22 of 23 patients are shown in Table 1. The one patient with increased intraepithelial lymphocytes as the only abnormality was a woman in whom celiac disease had been diagnosed 24 years earlier and had been on a strict gluten-free diet during that time.

Serological results: Titres of IgA tTG antibody ranged from 6 to $73,000 \mathrm{AU} / \mathrm{mL}$, with a median of $13.5 \mathrm{AU} / \mathrm{mL}$ (reference range 4 to $60 \mathrm{AU} / \mathrm{mL}$ ). The titres are shown in Figure 1. Three patients had raised titres. The first, a 63-year-old woman with CC, had a titre of $68 \mathrm{AU} / \mathrm{mL}$. Results of a small bowel biopsy were normal, and the authors plan to monitor clinical symptoms and repeat the serological titres.

The second patient was a man in whom celiac disease and LC had been simultaneously diagnosed nine months earlier. His tTG antibody titre was $209 \mathrm{AU} / \mathrm{mL}$. His symptoms had completely resolved with gluten-free diet; therefore, a further duodenal biopsy was not performed.

The third patient had a tTG antibody titre of 73,000 AU/mL. He was a 78-year-old man with LC in whom small bowel biopsy showed moderately severe villous atrophy with crypt hyperplasia. This man was the only patient who demonstrated $\operatorname{IgA} \mathrm{EmA}$; the remaining samples were all negative.

\section{DISCUSSION}

$\mathrm{CC}$ was first described in three patients with a watery diarrhea syndrome in two independent reports in $1976(13,14)$. Both described a subepithelial collagen band in the lamina propria associated with increased lamina propria lymphocytes and plasma cells in macroscopically normal colonic mucosa. Several other reports of similar clinical and pathological features have been published since then. Women are more commonly affected (nine to one), and typically the patient presents in the sixth to seventh decade of life (1).

LC demonstrates similar clinical features to CC, particularly watery diarrhea. Typically, the colonic mucosa also appears normal macroscopically, but histologically shows surface epithelial damage with increased intraepithelial lymphocytes and chronic inflammation in the lamina propria, but no subepithelial band occurs. Unlike CC, LC affects males and females equally (1). CC and LC should be considered to be separate but similar conditions, although conversion of LC to CC has been described in a few cases $(1,2)$.

In celiac disease, villous atrophy occurs along with crypt hyperplasia and increased crypt mitoses. Lymphocytes are increased in both the epithelium and the lamina propria (15). In addition, colonic lymphocytosis is frequently seen in patients with celiac disease (16). In contrast, however, celiac disease is closely linked with human leukocyte antigen (HLA) DR3, DQ2, but no HLA associations have been 
found for either CC or LC (2). Celiac disease occurring in cases of both CC and LC has been described in the literature (3-6). Two of these studies looked for celiac disease in patients diagnosed with CC $(3,6)$. The first study found four cases of celiac disease in 10 patients with CC, the second found a much lower prevalence, with only one case out of 45 . Two further studies $(17,18)$ tested patients with CC or LC for serological markers of celiac disease. IgA antireticulin antibodies were found in one of 29 patients with $\mathrm{CC}$ and none of 21 with LC-a similar prevalence to that found in the general population (17). IgA EmA was present in one patient of 38 with CC (18).

In our own department, loading the diet of two patients with LC with gluten failed to induce small intestinal changes (19), suggesting that, in these patients at least, no celiac latency existed. In view of this, 15 patients with $\mathrm{LC}$ and eight with CC were tested for IgA EmA and IgA tTG antibody to look for serological evidence of celiac disease. One new case of celiac disease, in addition to three previously diagnosed cases, was found - all patients with coexisting LC - resulting in a prevalence of four of $15(27 \%)$. None of the eight patients with CC had biopsy-proven celiac disease, although one woman did have slightly elevated titres of IgA tTG antibody. Although other serological markers have been found to predict development of celiac disease $(20,21)$, this has not been proved with tTG antibody. If we had chosen to use

\section{REFERENCES}

1. Giardiello FM, Lazenby AJ, Bayless TM. The new colitides. Collagenous, lymphocytic, and diversion colitis. Gastroenterol Clin North Am 1995;24:717-29.

2. Jawhari A, Talbot IC. Microscopic,lymphocytic and collagenous colitis. Histopathology 1996;29:101-10.

3. Armes J, Gee DC, Macrae FA, Schroeder W, Bhathal PS. Collagenous colitis: Jejunal and colorectal pathology. J Clin Pathol 1992;45:784-7.

4. O'Mahony S, Nawroz IM, Ferguson A. Coeliac disease and collagenous colitis. Postgrad Med J 1990;66:238-41.

5. DuBois RN, Lazenby AJ, Yardley JH, Hendrix TR, Bayless TM, Giardiello FM. Lymphocytic enterocolitis in patients with "refractory sprue". JAMA 1989;262:935-7.

6. Zins BJ, Tremaine WJ, Carpenter HA. Collagenous colitis: Mucosal biopsies and association with fecal leukocytes. Mayo Clin Proc 1995;70:430-3.

7. Volta U, Molinaro N, De Franceschi L, Fratangelo D, Bianchi FB. IgA anti-endomysial antibodies on human umbilical cord tissue for celiac disease screening. Save both money and monkeys. Dig Dis Sci 1995;40:1902-5.

8. Ladinser B, Rossipal E, Pittschieler K. Endomysium antibodies in coeliac disease: an improved method. Gut 1994;35:776-8.

9. Sategna-Guidetti C, Grosso SB, Bruno M, Grosso S. Is human umbilical cord the most suitable substrate for the detection of endomysium antibodies in the screening and follow-up of coeliac disease? Eur J Gastroenterol Hepatol 1997;9:657-60.

10. Dieterich W, Ehnis T, Bauer M, et al. Identification of tissue transglutaminase as the autoantigen of celiac disease. Nat Med 1997;3:797-801.

11. Dieterich W, Laag E, Schöpper H, et al. Autoantibodies to tissue transglutaminase as predictors of celiac disease. Gastroenterology 1998;115:1317-21.

12. Sulkanen S, Halttunen T, Laurila K, et al. Tissue transglutaminase these serological tests as screening tools to identify patients in whom small bowel biopsy was indicated, no patient with celiac disease would have been missed and only one patient would have undergone a biopsy for a false positive tTG antibody titre. This suggests, therefore, that celiac serology may be a useful screening tool to identify patients with CC or LC in whom small bowel biopsy is indicated.

A direct pathogenic link between celiac disease and either CC or LC has not yet been elucidated. Although all three conditions demonstrate similar histopathological features, it is unclear whether the reported coexisting cases have occurred by chance or are due to a common mechanism. The studies that have been performed to try to clarify whether an association exists, including this one, have all involved small numbers of cases, making conclusions impossible. The reported incidences of CC and LC vary from $0.3 \%$ to $5 \%$ of patients investigated for chronic diarrhea $(22,23)$, and the relative rarity of these conditions probably accounts for the difficulty in studying large numbers of cases. Ideally, a large multicentre study to examine the prevalence of celiac disease occurring in association with these colitides should be performed.

ACKNOWLEDGEMENTS: This work has been supported by a research grant from the Canadian Celiac Association, Vancouver Chapter, Vancouver, British Columbia. autoantibody enzyme-linked immunosorbent assay in detecting celiac disease. Gastroenterology 1998;115:1322-8.

13. Freeman HJ, Weinstein WM, Shnitka TK, Wensel RH, Sartor VE. Watery diarrhea syndrome associated with a lesion of the colonic basement membrane (BM)-lamina propria (LP) interface. Ann R Coll Phys Surg Can 1976;9:45.

14. Lindström CG. 'Collagenous colitis' with watery diarrhoea - a new entity? Path Europ 1976;11:87-9.

15. Trier JS. Celiac sprue. N Engl J Med 1991;325:1709-19.

16. Wolber R, Owen D, Freeman H. Colonic lymphocytosis in patients with celiac sprue. Hum Pathol 1990;21:1092-6.

17. Greenson JK, Giardiello FM, Lazenby AJ, Pena SA, Bayless TM, Yardley JH. Antireticulin antibodies in collagenous and lymphocytic (microscopic) colitis. Mod Pathol 1990;3:259-60.

18. Bohr J, Tysk C, Yang P, Danielsson D, Järnerot G. Autoantibodies and immunoglobulins in collagenous colitis. Gut 1996;39:73-6.

19. Freeman HJ. Failure of added dietary gluten to induce small intestinal histopathological changes in patients with watery diarrhea and lymphocytic colitis. Can J Gastroenterol 1996;10:436-9

20. Collin P, Helin H, Mäki M, Hällstrom O, Karvonen AL. Follow-up of patients positive in reticulin and gliadin antibody tests with normal small bowel biopsy findings. Scand J Gastroenterol 1993;28:595-8.

21. Mäki M, Holm K, Koskimies S, Hällstrom O, Visakorpi JK. Normal small bowel biopsy followed by coeliac disease. Arch Dis Child 1990;65:1137-41.

22. Shurberg J, McCoy K, Yardley J, Travers R, Giardiello F, Lazenby A. Collagenous colitis seen in 1320 patients with chronic diarrhoea in a community practice of gastroenterology from 1976 to 1986. Gastroenterology 1988;94:A426. (Abst)

23. Gineston J, Sevestre H, Descombes P, et al. Biopsies of the endoscopically normal rectum and colon: a necessity. Incidence of collagenous colitis microscopic colitis. Gastroenterol Clin Biol 1989;13:360-3. 


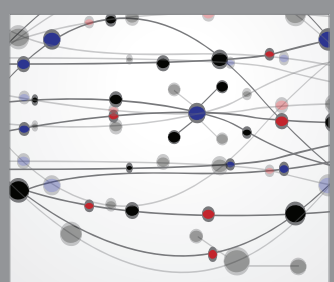

The Scientific World Journal
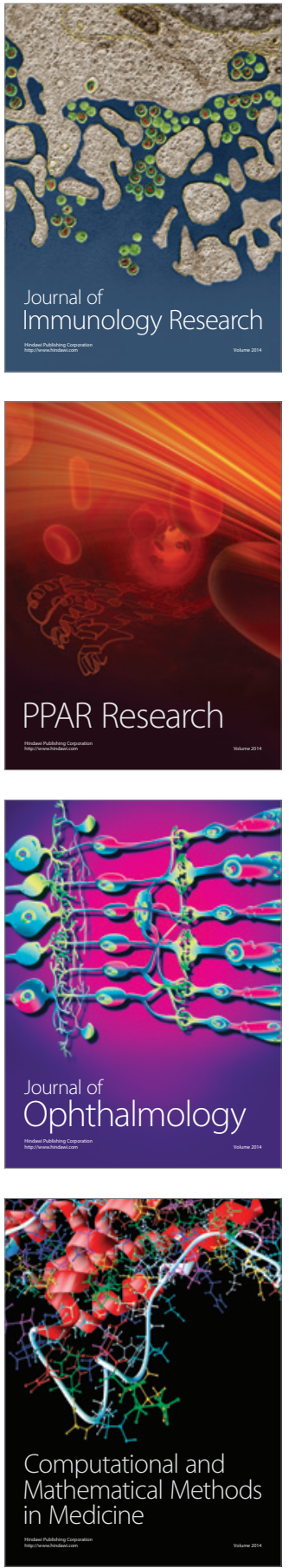

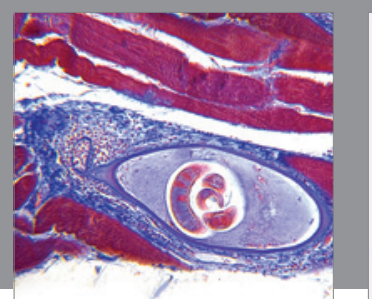

Gastroenterology Research and Practice

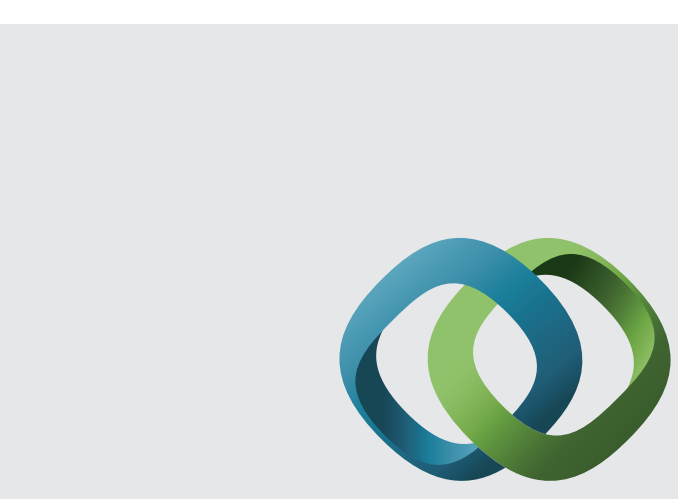

\section{Hindawi}

Submit your manuscripts at

http://www.hindawi.com
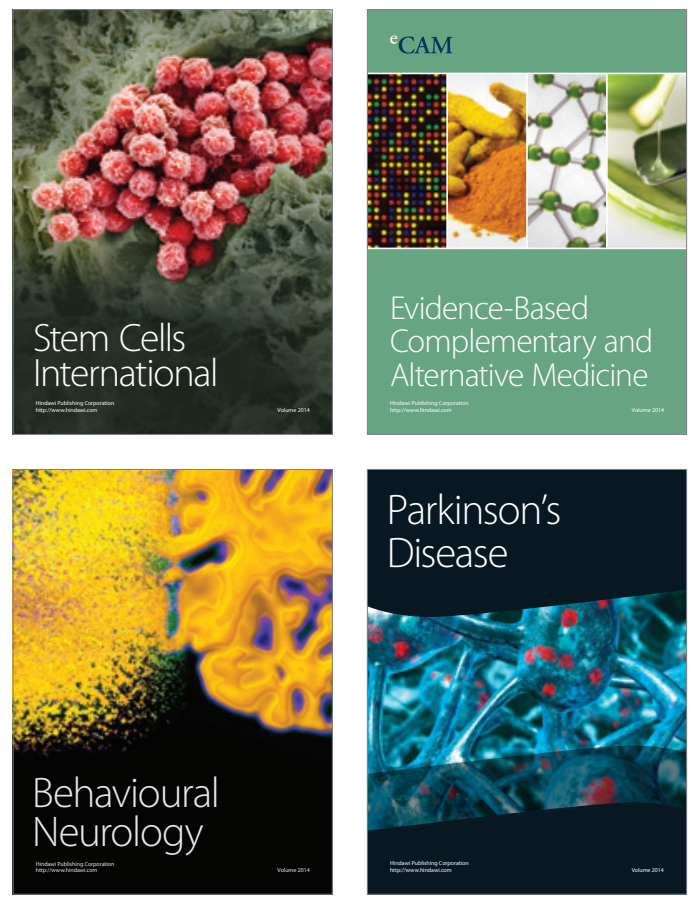
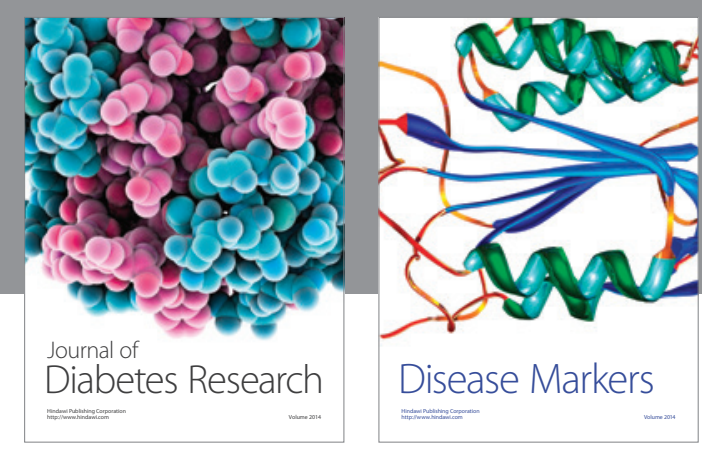

Disease Markers
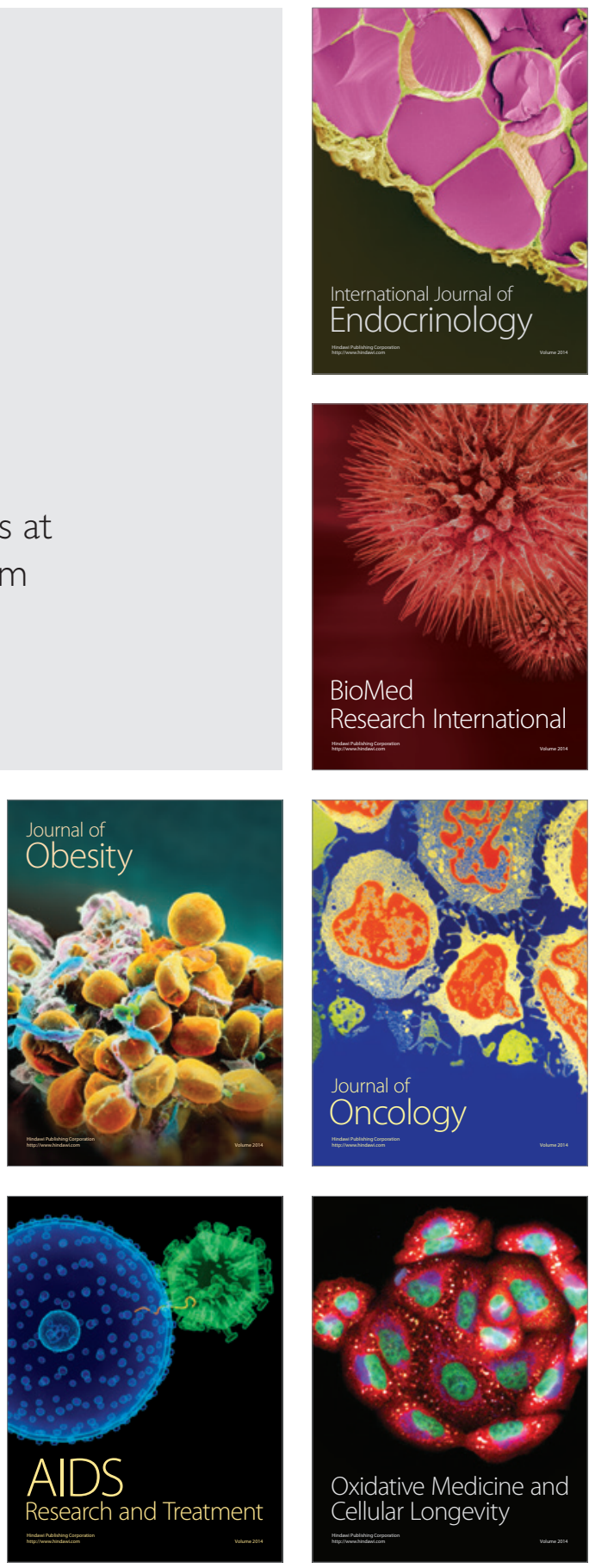